\title{
The Place and the City: Trends in the Construction of the Public Space
}

\author{
Andreina Maahsen-Milan ${ }^{1}$, Luigi Oliva ${ }^{2, *}$ \\ ${ }^{1}$ Alma Mater Studiorum, University of Bologna, Department of Architecture, Via Risorgimento 5, Bologna, Italy \\ ${ }^{2}$ University of Sassari, Department of Architecture, Design and Urban Planning, Piazza Duomo 6, Alghero (SS), Italy \\ *Corresponding Author: luigi.oliva@uniss.it
}

Copyright (C 2014 Horizon Research Publishing. All rights reserved.

\begin{abstract}
This paper analyses the evolution of the concept of public space in the European city in a diachronic framework, from its historical and foundational functions to the opportunity it provides to trigger regenerative strategies in socially and environmentally degraded urban contexts. The specificity of 'potentially public' spaces resides in their peripheral position inside metropolitan areas and in their episodic and fragmented character. This autonomy with respect to other typologies of free spaces appears to require the elaboration of specific analytical approaches and design models that move from the explicit recognition of the reticular structure of the territory. Examples of urban regeneration promoted in the last decade, in general supported by the European Union, open new perspectives on urban governance that are implicitly based upon the role of social inclusion in welfare and sustainability policies.
\end{abstract}

Keywords Public Space, Urbanism, Participation, Urban Governance, Enclaves

\section{Introduction}

Contemporary western cities, particularly in Europe and the United States, have been submitted to expansion-contraction processes based on economics that bring into question territorial continuity, sustainability and the urban image. Management issues relating to mobility, safety, energy, and decay are the external manifestations of such crisis. On the social plane, the deep disarticulation of the urban space is an important symptom. The spaces, services and common functions around which the city arose and became organized have themselves grown in size and complexity during the successful decades of the welfare state. The 'locations' destined to meet health, sports, recreation and cultural needs were built for an growing citizenry, increasingly aware of their own rights, and were added to the existing locations of the historical city-Greek, Roman, Medieval and Renaissance. Awareness of the need for an articulated, holistic 'public city' grew from a phase of closure and fragmentation [1]. The public city is constituted by a set of spaces, services, equipment and networks that have become standard and necessary features, integrated into life around accommodation and places of production and exchange.

Contemporary urban planners recognize that the character of life between buildings varies according to the particular social situation, yet they still apply a set of standard categories in the construction of public spaces, believing that the essential principles and criteria to be applied in working towards outcomes of human quality are remarkably constant [2]. Positioning himself as some combination of technician and flâneur, the 20th century urban planner has been mainly involved in top-down processes [3].

The cornerstone of a conference held at the City University of New. York (CUNY) Graduate Center entitled "The Politics of Public Space" in 2005 was the recognition that public spaces in the US have become centers of commerce, consumption and places of political surveillance, rather than democratic places where a diversity of peoples and activities are embraced and tolerated [4].

At the same time, Mitchell was breaking down ideas of planning and control in the US city, in favor of the new social and cultural integration of citizens that was happening in public spaces [5].

In 2002 Avritzer showed that democratic collective action has opened up a new public space, in the discursive sense, for popular participation in Latin American politics [6]. On the opposite side, in Mexico City, Lawrence noticed that the increasing power of global corporations is leading to an urban condition that can be best described as fragmented, one in which decision making is increasingly decentralized to suburban towns, where space is more and more privatized, and where physical sprawl and the dominance of the automobile are creating a city that is overly privatized, ego-driven and individualized, and where civic consciousness is in steady decline [7]. Both trends are evident in the Brazilian city, where the public space is undergoing transformations that point toward opposite directions. One direction heads to a stronger seclusion of all social groups in their protected "home" spaces, while the 
other heads to the betterment of quality of public spaces at large, from neighborhood plazas to downtown revitalization [8].

Since the beginning of 21 st century, the growing concern for sustainability led urbanists to consider economic and social matters from a different point of view, taking into account important factors such as resilience, informal economies, and land and environment consumption [9] [10] [11].

Other important roles in space regeneration are played by arts and technology. City authorities all over the world are deploying strategies for mastering the new interdisciplinary planning for smart cities and the interlinked layers of digital technology, people-driven innovation ecosystems, urban activities and infrastructure. Internet of Things (IoT) is considered as a major research and innovation stream leading to plenty opportunities for new services by interconnecting physical and virtual worlds with a huge amount of electronic devices distributed in houses, vehicles, streets, buildings and many other public environments. The recommendation is for integrated solutions involving communities of citizens, IoT platforms, and services targeted at the problems of different city districts, sectors, and utilities. [12] [13].

Cohesion and sustainable policies on urban regeneration represent a very substantial part of the budget of the European Union. The following case studies stress the important role of public space as an indicator of the quality of sustainable communities, focusing on some successful or spontaneous (bottom-up) experiences. The quality of places has been related to improvements in quality of life (both perceived and concrete), urban form (spatial relations), and concentration of services. These factors assist in appraising the function of the community gathering spot, its tendency to host special events, and enhancement of the "sense of place", or modern-day version of the Greek agorà [14].

\section{Methods and Materials}

A detailed survey of recent experiences in urban regeneration and policies for public space has been compared to trends in urban design, traced through several publications on this theme.

What follows is a multidisciplinary analysis of the evolution of the traditional concept of 'city as system' into the cutting-edge concept of city as complex adaptive organism [15]. The aim is to highlight innovative aspects and elements of European and American urban communities and to define paths and forms of sociality in relation to the construction of the cityscape [16].

\subsection{The Role of Profit}

For the so-called 'profit city', which obeys purely economic criteria, services and standards are a financial burden, because the speculative construction margins are reduced; however, they are also an advantage, because they improve the liveability of urban spaces [17]. The negative consequences of the reduction of public space are easily verifiable in the impoverishment of social spaces and their privatization, which reduces the essence of public life - places for encounters and discussion - to planned, paid services [18]. During the 19th and 20th centuries, the historic cities of Europe, including the welfare cities of Scandinavian social democracies, set up services to promote community that were logically differentiated and formally identifiable (from health to education, from sports to care). This actually altered, if not cancelled altogether, the traditional perception of the archetypical public space: the open and uncovered piazza was replaced by shopping malls or bazaars.

The demand for a user-friendly and more articulated presence of equipment, services, spaces and networks available to the community arises from the discomfort provoked by the loss of the urban apparatus, which is perceived as an essential asset. Moreover, new needs have emerged, completing and integrating old ones, so that they are not only functional but also redeployed according to the objectives that the European community intends to achieve by 2020 [19]. In this sense, cities need to evolve on the basis of performance and ethical, social, environmental, and aesthetic principles, in terms of:

a. Energetic sustainability

b. Responsible use of natural and soil resources

c. Recognizability and aesthetic quality in the overall urban form. Architectural objects must be 'beautiful', but also must balance each other out and provide a sense of pleasure, fully recognized and shared.

d. Social and cultural equity in the use of 'life spaces'.The city, in the articulation of public space and services, must remove the obstacles to integration, i.e. discrimination based on ageing, health, gender, social classes or citizenship. The city must provide opportunities for individual and community growth; these progressive terms, despite the objective difficulties in their application and implied additional costs, cannot be ignored or neglected for the sake of states' balance sheets.

\subsection{Limits of 'Private' and 'Public'}

The housing sector has always had a very rich role to play in the field of the 'public city', both in the traditional European urban form and in the 'welfare city'. The house, a place of permanence but also of creation, is a 'private place', but is not necessarily in opposition to the public space. It suffices to observe the plan of an ancient or medieval Italian city, such as Rome or, better yet, Naples, which Walter Benjamin [20] regarded as the model of a porous city. There are places of exchange and intermediation between public and private, between the two polarities, through refined intensities and nuances: from the private nucleus of the domus to landings, stairs, courtyards and entrance halls, to the road and the public dimension of the piazza, understood 
as the ius romano, i.e. the legal, institutional realm [21]. The same characteristics can be found in the typological tradition of Venetian trading palaces (12th-16th centuries) or the houses and workshops of the German Hanseatic cities, which brought negotiatory, contractual, and social relations inside.

The charity tradition of the European historical city was initially based on protective forms, or social mitigation with professional origins (e.g. the guilds for the protection of widows and single women; Kramer-Witwen Housing, Hamburg, 18th century) [22] (Figure 1) or confessional origin (houses for poor craftsmen, Corte Cà Lando, Padua, Italy, 1513) [23]. These provided the prerequisites for the application of forms of equity and support to the poor classes who could not even afford cheap accommodation. Their elaboration in social terms became the basis for the establishment of civil rights, continuously threatened and questioned by the crisis of the social state.

\section{Results}

Several essays and recent studies of urban phenomena tend to underline the fact that one of the most obvious aspects of the deep transformational processes connected to globalization is territorial fragmentation, especially of metropolitan areas. From a spatial point of view, fragmentation entails a configuration of 'islands', some characterized by an efficient system of inter-relations, others disconnected or involved in processes of progressive marginalization. This subdivision into multiple units inverts the logic of the 'mosaic', in which each single part acquires meaning only inside a bigger picture. It is a phenomenon that has appeared in a different form in the South American metropolis, where this particular spatial configuration is the visible image of social fragmentation, the outcome of a series of processes that began in the early 1980s with changes in the organization of work followed by technological innovation and new patterns of consumption [24].

Complex and historically consolidated European cities such as Turin or Bologna (industrial Italian capitals of mechanics and trade) or the German manufacturing cities of the Rhineland (which specialized in the textile industry) managed to 'keep it together' in physical terms, but surrendered their internal urban features. In terms of the social cohesion of the different settled groups, every attempt at physical recovery of the urban fabric turned out to mean gentrification, the negative consequences of which are becoming increasingly evident each day.

The increasing and diversifying uses of space correspond to this fragmentation, to the point that it has become what sociologist Zygmunt Bauman characterizes as 'liquid' [25]. Both increase and diversification are crucial factors in triggering the phenomena of polarization-marginalized 'islands', ghettos or gated communities, voluntarily isolated from what is perceived as a 'dangerous' diversity. They both generate a widespread perception of insecurity, 'grey areas', 'otherness', the threat of the 'autochthonous' (i.e. the 'natives', the 'old citizens') to the 'allochthonous' (the 'new citizens').
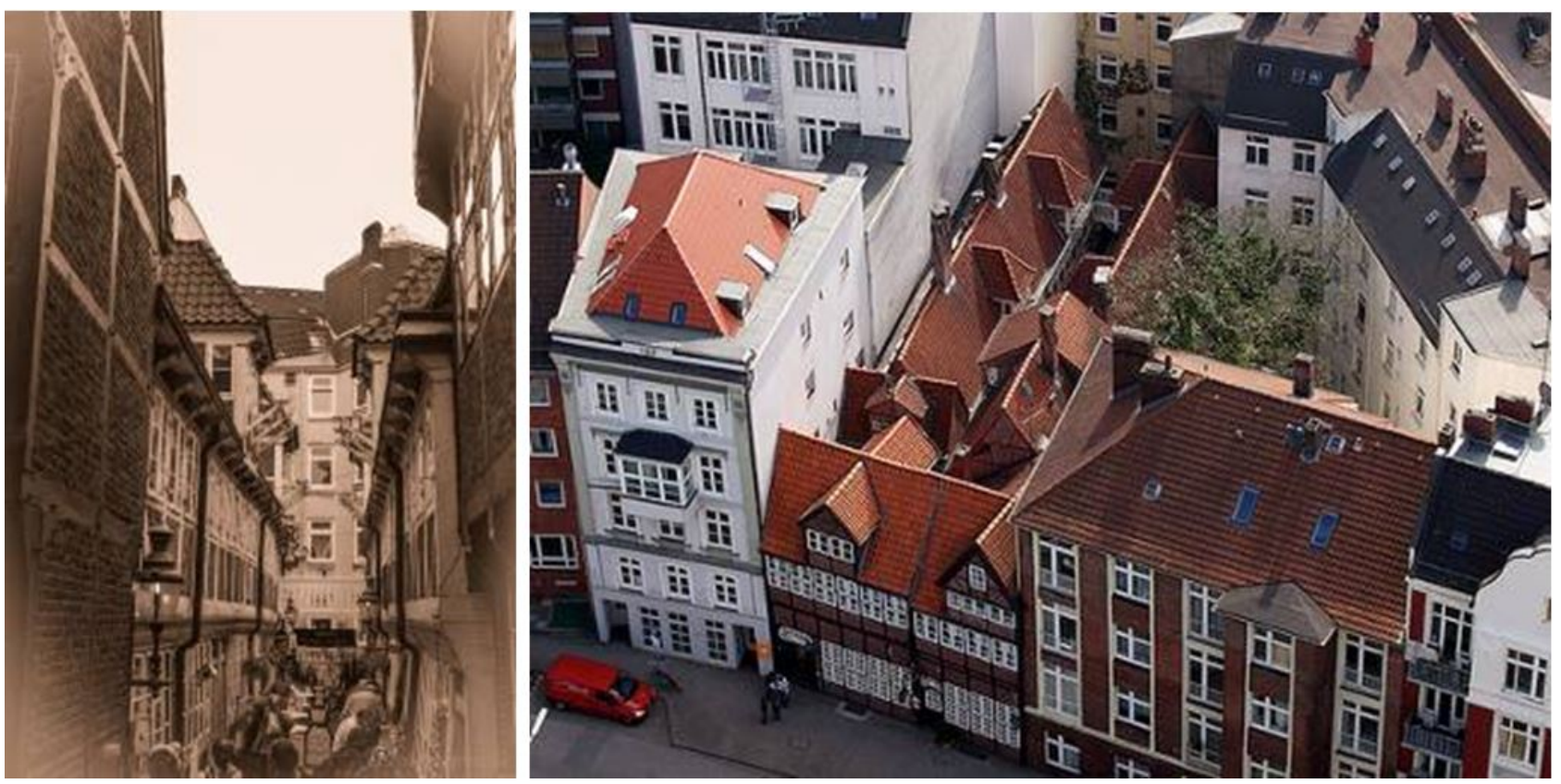

Figure 1. Kramer-Witwen housing, Hamburg, 18th century. 


\subsection{The Construction of Identity}

The logic of our reasoning in European geographical and cultural contexts must be checked against historical examples that have arisen in different technological conditions but ones with similar social and cultural features. Venice, a model of polycentricism and a cultural one-off, is one such example. From Venice's foundations in late antiquity to the high medieval period, to its consolidation as a multicultural metropolis (13th-16th centuries) (Figure 2), to its current urban contraction and media explosion, it is possible to identify some consistency in the laws governing its make-up of modular repetition and standardized collective spatial patterns. In Venice, we can see how the constitutive island, the basic cell of the entire living being of the lagoon city, was initially founded on endogenous and enlarged kinship 'groups'. Each island is a recognizable, autonomous element, characterized by the presence of the parish church, the common campo [26], the calle (narrow streets), and the canals, bustling where the flows of life mix with the ancient flows of nature. Such readings, initiated at the Scuola Veneziana di Architettura by Saverio Muratori (1959), have developed into a flourishing school of study, resumed with new vitality by Elena Manzo in her sociological research at the University of Milan [27].

\subsection{The Space of Communities}

The history of the urban morphology of Venice demonstrates how the 'island' configuration, in exceptional circumstances (i.e. those that generated the lagoon settlement), developed slowly but surely by tearing down physical barriers and filling moats. It is not by chance that Venice improved its own urban performance, primarily through interventions of urban rationalization, unifying minimal units into more efficient functional elements. This approach is also identifiable in late baroque Italian cities, where continuous land works mirrored complex representational civil values and daily needs. A good example is the construction of the famous Piazza Pra' della Valle in Padua, which was obtained by reclaiming a marshy area, its long evolution dating back to the Roman age, the layout of which is still under discussion and modification. Similarly, the space that surrounds the ancient cathedral in Cologne (Figure 3), one of the most restless public spaces in the world, has been continuously modified since the Middle Ages through endless competitions, debates, constructions and reconstructions. This physical union is an almost obligatory passage that precedes, follows or accompanies the eternally conflicting relationship between groups, in a circular process of integration and exclusion, or, as Giovanni Battista Vico (1668-1744) theorized, 'in the course and recourse of history'.

The idea of a community as a place to share fears, real or imaginary, overcomes the idea of empathetic collective expression. It is not by chance that the 'island' occupies a special place among fictional spaces. Thus the accent seems to fall on aspects of separation rather than on relational values, which instead characterize the archipelago.

\subsection{Expansion and Contraction}

This tendency of polarity between local and global, examined from the point of view of social behavior, results in the breaking of bonds between individuals and their own territory (community) and the establishing of new ones; for example, spiritual-friendly bonds are maintained with 'elective motherlands' or the 'expansive universe' of the web [28]. This entails the acknowledgment of differences with the other, who can quickly become the antagonist.

The space of flows [29] sits alongside the topos of the metropolitan space as a place of fragmentation: in this sense, the metropolitan territory is a support for material and immaterial networks, as pulsing as a living body in a vision that oscillates between control and response to stimuli in pursuit of satisfaction and projection or desire. Thus the reticular metaphor can also imply that places-islands and archipelagos - can be perceived as temporary elements in a territory of vast diasporas, in which 'other' collective memo ries and exchange practices are produced that identify 'sedentary' and 'migrant' populations or urban nomads.

A further implication concerns the possibility of operating targeted disconnections, generators of processes of social marginalization and a loss of control over urban territorial relationships. One example is found in the ghettos and nomadic camps that pulse around large Italian cities, as are also, though in a different way, the 'gated communities', offshore residential islands and tourist resorts [30].

On another level, economic contraction processes produce fraying of the urban fabric and the abandonment of whole areas [31]. This results in a loss of relevance of the physical territorial dimension in favor of immaterial factors, such as procedures and policies, the negative outcome of which has been the putting into crisis of the traditionally technical professional identity of architects, to the advantage of almost wholly bureaucratized and abstract decision-making units. In many European cases, and in the Italian one in particular, there has been a shift from master plans without policies to master plans with policies devoid of any territorial references.

The outcome has been an image of the city conceived via 'autonomous projects', abandoning the procedure of the shared and unifying narrative [32]. In peninsular and mainland Europe, the 1980s triggered processes of renovation of derelict areas and disused industrial sites [33], seizing the opportunities offered by the modernization of infrastructures. At the same time, the de-localizing choices of large shopping centers stimulated urban sprawl. New living styles and neo-liberal deregulation policies have allowed a substantial reduction in the planning of vast areas. The affirmation of totally inconsistent low-profile localisms is another negative element. 


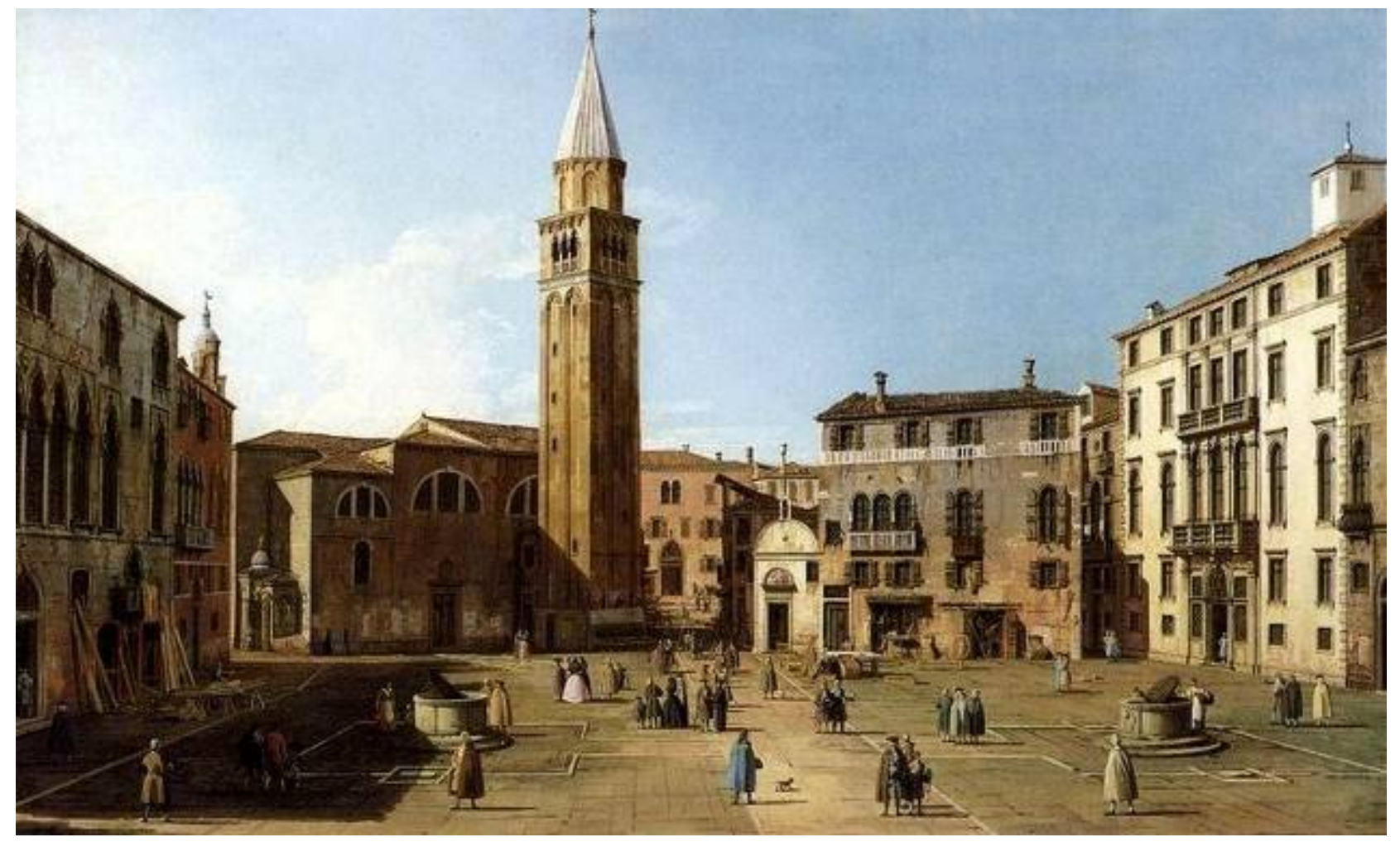

Figure 2. Canaletto (Giovanni Antonio Canal), 'Campo Sant'Angelo', Venice, 18th century.
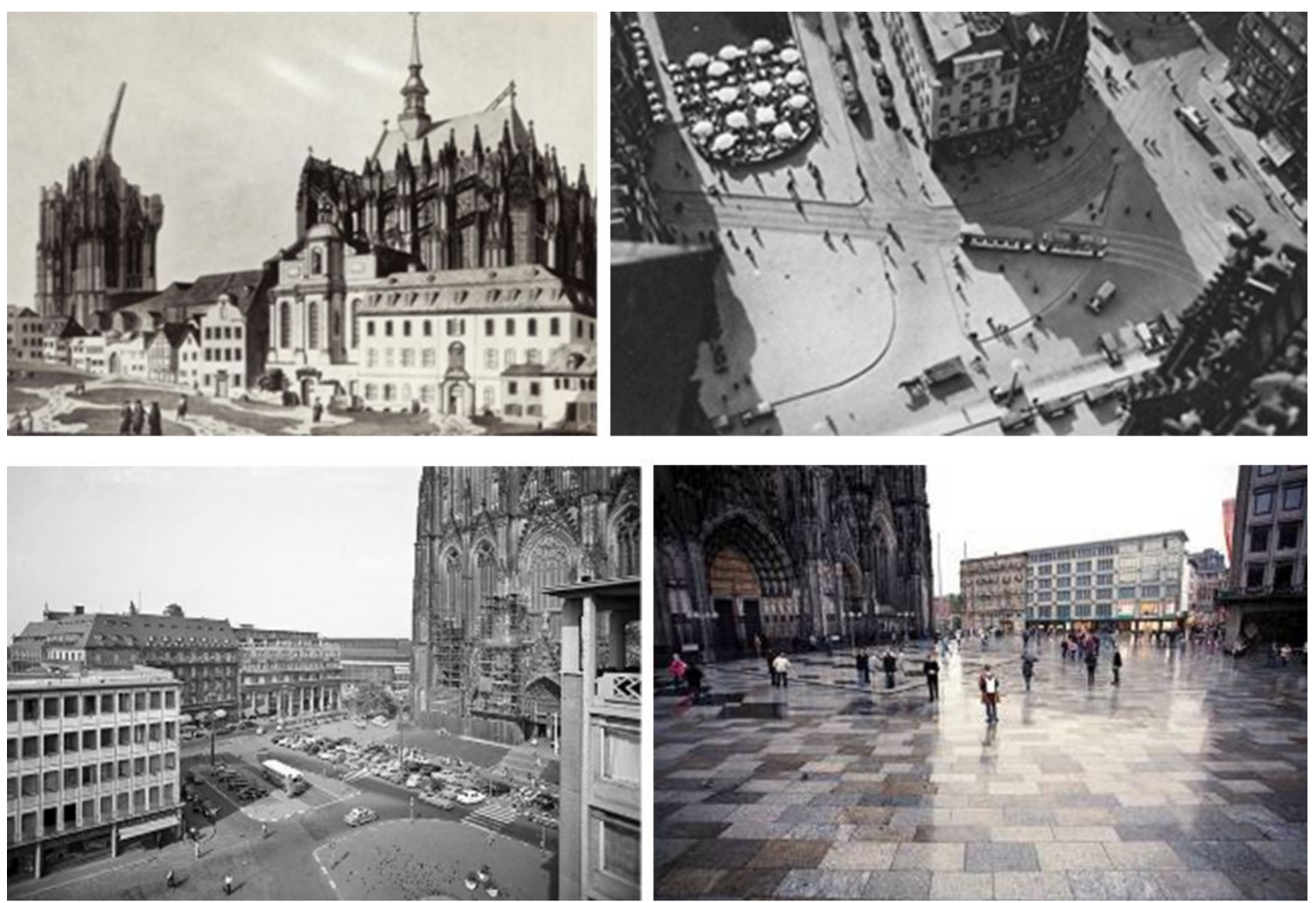

Figure 3. Cologne, Cathedral square, years (top-right): 1796, 1940, 1957, 2010 


\subsection{Whose is That Land?}

Experimentation in problematic areas-such as the metropolitan area of Rome, where there is a growing demand for safety-also highlights the need to favor processes of community construction in terms of the 'configurative' [34] design of built and relational spaces. In this respect, the free residual spaces included in metropolitan areas are not just an opportunity for innovative experimentations but also, as marginal spaces, a kind of 'no-man's-land', they are susceptible to illegal slumming [35] by 'new poverty' [36] individuals. These borderlands, awaiting new configurations and consumed through improper and temporary uses, are distinct from the 'city of projects'. The ability to seize and single out the potential of these urban 'ready-mades' opens up a functional horizon to mitigate, if not resolve, problems of spatial inequality.

This cellular connected fabric is the terrain for experimentation, evolution and testing of urban planning. Thus, the capacity of the city (and of society) to integrate problematic, marginal individuals within a shared system of citizenship rules is measured in such transition spaces, each a 'no-man's-land' in the social and physical sense.

The informal economic character (collective or individual) of these unprecedented forms of marginality and their self-propelled, temporary nature make them uncontrollable. This means a willingness to reserve judgment or put aside the usual spatial considerations in terms of urban governance, which is often more focused on their prevention and control, motivated by a growing demand for safety and selectivity of presences in public spaces.

Many studies on urban sprawl [37] underline its public and collective costs. The need for methodological tools is highlighted alongside normative solutions in drafting long-term scenarios upon which consensus can be built. 'Imaginative nature' is also a device able to generate processes, some of which are unpredictable, related to technical social networks: a world of interconnections between subjects and objects, discussions based on sustainability in a broader sense (environmental, economic and social) [38]. This finds particular consonance in the 'social ecology' of the United States [39], in the environmental policies of the European Union [40] and in China's experiences [41]. The declared objective is to restore a bigger and more widespread porosity, permeability and accessibility to urban spaces, and to design them with ambition by taking into account the quality of the cities that came before and reasoning again on the basis of the collective [42].

\subsection{Participation: A Religious Concept?}

Many policies implemented with regard to cities, particularly in the European Union, have adopted the approach of evaluating urban assets from the perspective of presences and encounters rather than physically defined perimeters [43]. In this way, it has been possible to enhance the design vision, making it more nuanced and intricate. New pedestrian systems for social areas have been experimented with; green corridors have been created, connecting the city center to outlying areas [44]; car parks have been built next to historic sites; and open spaces have been re-worked according to a logic other than that of profit-seeking.

To improve the efficacy of administrative action, the focus has been placed on the integration of sectors and different levels of administration, organized representatives of economic interests and associations of active citizenry.

Communal projects are characterized by preparatory, organic and unitary schemes that integrate the policies of different administrative sectors. Projects have dealt with the re-design of connections between peripheral neighborhoods and the city center; the creation of ecological urban networks, traffic calming measures, landscaping projects or new pedestrian areas; the distribution of services in run-down neighborhoods; the use of public transport to redefine spatial and network relations; the recovery of disused buildings to support youth entrepreneurship projects; and the establishment of urban workshop start-ups to integrate the actors of processes.

Although a systematic framework of knowledge about this extraordinary and changeable associative reality is still missing, it is important to point out how, in recent years, coordination groups have been created in Italy that have made efforts to open up the network to spontaneous thematic aggregations or territorially homogeneous consolidated institutions. This has been the case in the case of the successful Tuscan network and similar attempts in the northern regions of Veneto and Lombardy. Even more numerous are the groups coordinating inter-municipal and sub-regional networks - these are especially active in the Veneto mainland of Padua and Venice - or metropolitan networks, particularly in the most industrialized regions (Piedmont, Veneto, Lombardy, Tuscany and Lazio). Coordination at a cross-border level is interesting; it has occurred spontaneously, on the initiative of several young architects and urban planners, in the cases of Trieste [45], an Adriatic port city bordering Italian, German and Slavic cultures, and Forlì [46]. These have drawn national and international attention (through the ATRIUM program of the EU) [47] to the abandonment and the necessary re-use of abandoned spaces as a strategy of economic and social progress, particularly with regard to youth employment and the recovery of the vitality of run-down urban areas.

These cases open up new perspectives on urban governance, implicitly based on the need for social inclusion in welfare and sustainability policies. Frankfurt's GrünGürtel GmbH [48], the Ruhr's IBA and the Agence des Éspaces Vertes (AEV) d'Île-de-France in Paris [49] represent intermediary structures between public institutions and the different political and social forces involved. In the city of Frankfurt, the creation of an independent coordination society for green belt design and management has been one of the factors that have determined the project's success, particularly because it enjoyed great technical and financial autonomy. 
In Rome, emblematically classified as a 'spontaneous metropolis' [50], new research in the field of protecting the local urban milieu has been experimenting with the posting of projects on the Internet, focusing on the recognition of the identity and values of each area (archaeology, traditions and cultures). In these projects, the involvement of universities, students and young researchers has led to the birth of new professionalisms for the future participatory management of urban spaces [51].

Given these remarkable recent activities, it has been possible to undertake a series of statistical evaluations that reveal how solutions change considerably according to context. The proposals formulated and developed in areas characterized by communal identity (small towns, delimited neighborhoods, enclaves) have reached the highest levels of feasibility, resilience and sustainability. Areas characterized by social conflict, lack of territorial definition and low density do not achieve sufficient levels of participation and promotion, making necessary a preparatory phase of planning and centralized management. The intervention of professionals in support of processes turned out to be a fundamental variable, able to influence outcomes substantially. In particular, the most enduring results and the greatest involvement of residents and stakeholders were obtained where the whole process was constituted by a diversified and integrated framework with an equal emphasis on collaboration.

\section{Conclusion}

The specificity of spaces with 'public potential' resides in their peripheral position within metropolitan areas and in their episodic and fragmentary character. This autonomy with respect to other typologies of free space appears to require the elaboration of specific analytical approaches and design models. They have moved from the recognition of the complex structure of the territory with its narrative galaxy of collective and individual stories aiming at building different project images, each endowed with its own internal rules [52].

The debate over territorial and thematic contexts is broader than the local one. It increases awareness about the depth of the issue and makes the contribution of expert knowledge easier. It thus facilitates the overcoming of limits, competition and historical parochialism of networks and coordination. In the scope of the tormented city-countryside relationship [53], intensified by the expansion - spatial, not demographic - of European metropolises, the issues connected to the management of free spaces are once again conditioned by the fragmentation of private land and the prevailing of lobbies over the public interest, as well as the unbearable maintenance and management costs to the state. Here the impossibility of traditional planning actions is highlighted together with the need to resort to strategies like those experimented with in Italy (Rome, Milan Parco Nord [54], Tuscany, Veneto, Lombardy, Apulia), the United Kingdom [55], France (Lille, St. Denis, Strasbourg, Nantes [56], Bordeaux [57]) and Germany, especially regarding the housing and urban recovery policies of industrial-commercial infrastructures (Theresienhöhe in Munich [58]; ThyssenKrupp Headquarters in Essen [59]; the Ruhr Area [60]; urban regeneration of abandoned areas in Berlin) (Figure 4-5).

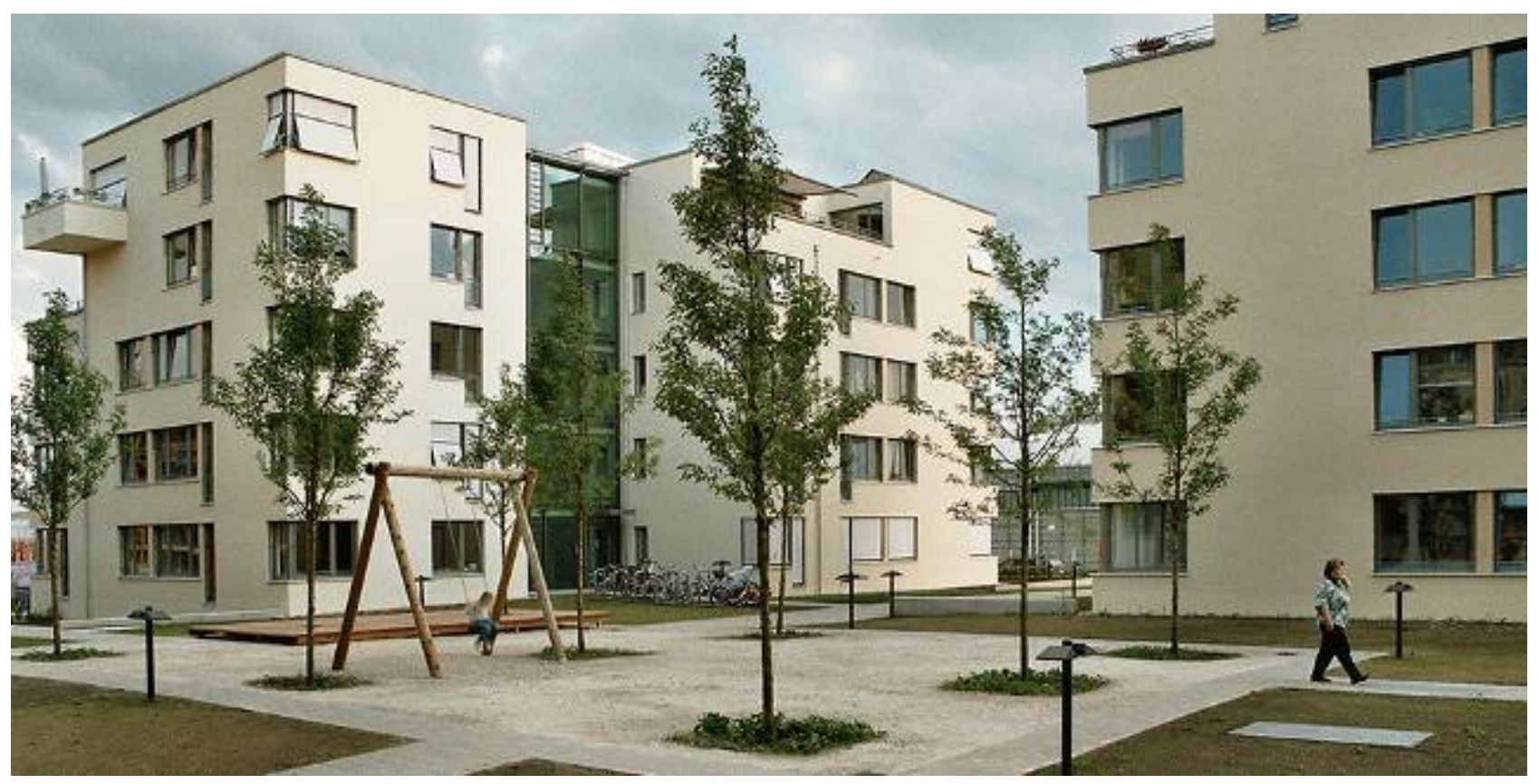

Figure 4. Delaossa Architects, Theresienhöhe, Munich. Landscape architecture by Rockinger \& Schneider. 

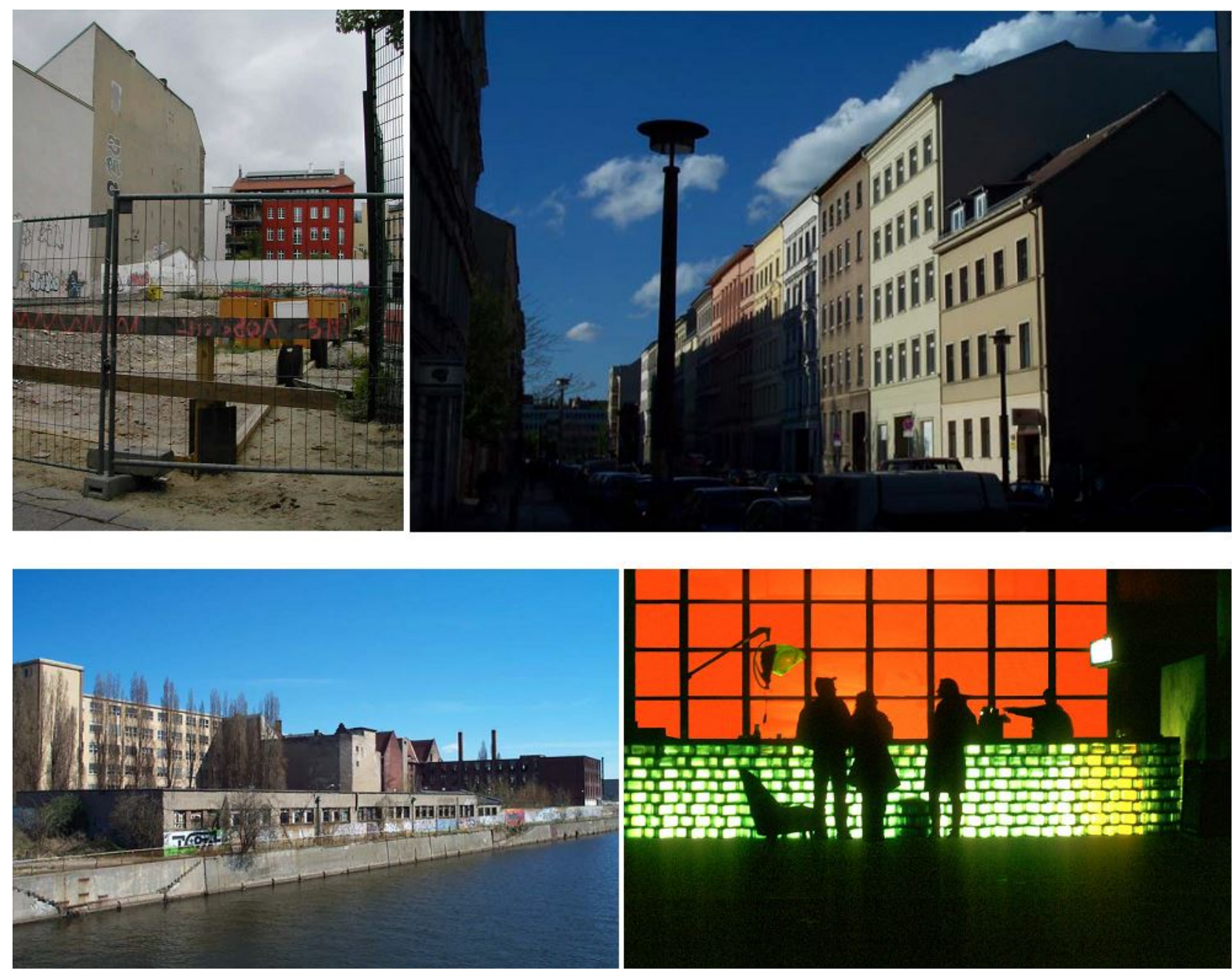

Figure 5. Berlin, Urban regeneration, 2012 (ph. Pietro Balp).
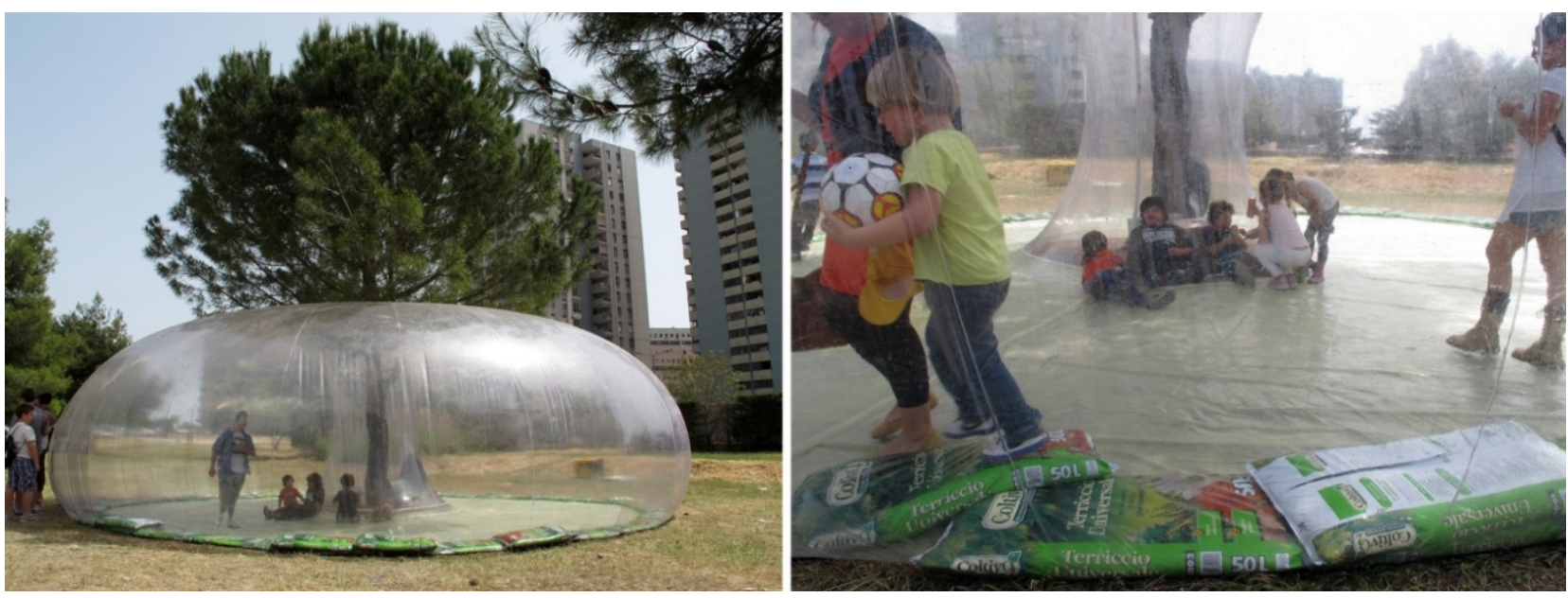

Figure 6. Taranto (Italy). Air structure representing the collective identification of an undetermined public space. May 1st, 2013.

Many European experiences appear to show that the creation of a dedicated agency for the participatory management of urban wastelands and marginal spaces is a guarantee of effective implementation. The novelty of current planning policies is highlighted by the participatory role of an active citizenry that is asking, with increasing confidence and competence, for decision making to incorporate a wider set of criteria with closer adherence to the needs of new, previously neglected, social lobbies (Figure 6). Although economic conditions are still critical, it is evident that a deep cultural revolution has taken place and endures, and that the physical body of the city will certainly 
be improved as a consequence.

\section{REFERENCES}

[1] Sorkin, M. (ed.). Variations on a theme park: The new American city and the end of public space. Hill and Wang, New York, 1992.

[2] Gehl, J. Life between buildings: Using public space. Island Press, Washington-Covelo-London, 2011.

[3] Whyte William, H. City: Rediscovering the center. Anchor, New York, 1988.

[4] Low, S. and Smith, N. (eds). The politics of public space. Routledge, New York-Abingdon (UK), 2006.

[5] Mitchell, D. The right to the city: Social justice and the fight for public space. Guilford Press, New York, 2003.

[6] Avritzer, L. Democracy and the public space in Latin America. Princeton University Press, 2002.

[7] Sassen, S. A Sociology of Globalization. W.W. Norton, New York, 2007.

[8] "Globalization, Politics and the Revitalization of Mexico City's Historic Center," in The Last One Hundred Years, The Next One Hundred, A. Rodriguez Kuri and S. Tamayo, eds., Autonomous University of Mexico (Universidad Autonoma Metropolitana), 2005, pp. 267-286.

[9] Vicente del Rio, Urban Design and the Future of Public Space in the Brazilian City in Jones, G.A and Ward, P.M et al., The End of Public Space in the Latin American City?, Memoria of the Bi-national Conference, The Mexican Center of LLILAS , University of Texas at Austin, 4-5 March 2004, pp. 12-15. Available electronically at: http://www.utexas.edu/cola/llilas /centers/mexican/publications/index.html. Last accessed 30 November 2013.

[10] Freilich, R. H. and Popowitz, N. M. The umbrella of sustainability: Smart growth, new urbanism, renewable energy and green development in the 21 st century. The Urban Lawyer, Vol.42, n.1, 2010, pp. 1-39.

[11] Talen, E. The social goal of new urbanism. Housing Policy Debate, Vol.13, n.1, 2002, pp. 165-188.

[12] McCormick, M. and Eichinger, H. Skypetrait: Portraits of urbanness, in McCormick M. and Eichinger, H. (eds.), Skypetrait: Transcontinental Faces. Stat Reutlingen, Reutlingen, Germany, 2013, pp. 74-77.

[13] Komninos, N., Schaffers H., and Pallot, M. Developing a policy roadmap for smart cities and the future internet. In eChallenges e-2011 Conference Proceedings, IIMC International Information Management Corporation. IMC International Information Management Corporation, 2011.

[14] Bernick, M. and Cervero R. Transit villages for the twenty-first century. McGraw-Hil, New York, 1997.

[15] Kelly, K. Out of control: The new biology of machines, social systems and the economic world. Addison-Wesley, Boston, 1994.

[16] Maahsen-Milan, A., Pellegrino, M., Oliva, L., and Simonetti,
M. Urban architecture as connective-collective intelligence. Which Spaces of Interaction?, Sustainability Vol.5, no.7, 2928-2943, 2013, doi:10.3390/su5072928.

[17] Moulaert, F., Rodriguez, A. and Swyngedouw, E. The globalized city: Economic restructuring and social polarization in European cities. Oxford University Press, Oxford, 2003.

[18] Affuso, O. and Jedlowski, P. (eds.). Sfera pubblica: il concetto e i suoi luoghi. Luigi Pellegrini Editore, Cosenza, 2010 .

[19] European Commission. Making our cities attractive and sustainable: How the EU contributes to improving the urban environment. 2010. Available at http://ec.europa.eu/environment/pubs/pdf/urban/cities_of_th e_future.pdf. Last accessed 15 September 2013.

[20] 'Porosity' is a term used by Benjamin to indicate the admixture (Durchdringung) or interlacing of the dimensions of time and space that characterises the living experience in a big city, Naples. Benjamin, W. Städtebilder. Frankfurt-am-Main, Suhrkamp, 1963 (Italian translation: Immagini di Città. Einaudi, Torino, 2007, pp. 6-15).

[21] 'City life, with its mutual and incessant encounters and crashes, is the condition and blueprint for every civilisation, not only political (which we think of immediately, faced with that Greek word) but also intellectual, ethical, economic, artistic, i.e. the whole development of a population.' Von Jhering, R., Lo scopo nel diritto. Einaudi, Torino, 1972, p. 75.

[22] Pabel, R. Im Schatten des Michel Das Kramer-Amt in Hamburg und seine Witwen-Wohnungen am Krayenkamp. Christians Verlag, Hamburg, 1978.

[23] Puppi, L., Universo, M., Le città nella storia d'Italia: Padova. Laterza, Bari, 1982.

[24] Lévy, J. Public space in a global perspective: Criteria and cultural dimensions. In Schmid, C., Acebillo, J., and Lévy, J. (eds.), Globalization of urbanity. Actar, Barcelona, 2012, pp. 94-111.

[25] Bauman, Z. Liquid modernity. Polity, Cambridge, 2000.

[26] A Venetian word for square, originally the contraction of camposanto ('cemetery'), a place between death and life.

[27] Manzo, E. La città che si rinnova: Architettura e scienze umane tra storia e attualità, Franco Angeli, Milano, 2012. See also the works of Paolo Maretto, Gian Luigi Maffei, Giancarlo Cataldi and Gianfranco Caniggia.

[28] Bauman, Z. Liquid life. Polity Press, Cambridge 2005.

[29] Castells, M. The rise of the network society. Blackwell, Oxford, 1996. See also Sassen, S. The global city: New York, London, Tokyo. Princeton University Press, Princeton, NJ, 2001.

[30] Petti, A. Arcipelaghi e enclave: architettura dell'ordinamento spaziale contemporaneo. Bruno Mondadori, Milano, 2007.

[31] Beyer, E., Hagemann, A., Rieniets, T., Oswalt, P. Atlas of shrinking cities. Hatje Cantz, Ostfildern-Ruit, 2006.

[32] Brenner, N. Between fixity and motion: Accumulation, territorial organization and the historical geography of spatial scales. Environment and Planning. In Society and Space, Vol.16, n.4, 1998, pp. 459-481. 
[33] Secchi, B. La città del Ventesimo secolo. Laterza, Roma, 2005.

[34] Configure (v.), late 14c., from Latin configurare, 'to fashion after a pattern', from con- 'together' (see com-) + figurare 'to form, shape', from figura 'a shape, form, figure'. Available at http://www.etymonline.com/index.php?term=configure. Last accessed, 17 September 2013.

[35] Inti I., Tipologie di spazi del riuso temporaneo. In Spazi urbani residuali e azioni temporanee: un'occasione per ridefinire i territori, gli attori e le politiche urbane. In Diss. IUAV, 2005.

[36] Neuwirth, R. Shadow cities: A billion squatters, a new urban world. Routledge, New York, 2005.

[37] Indovina, F., Fregolent, L., \& Savino, M. (eds.) L'esplosione della città, Editrice Compositori, Bologna, 2005. See also Camagni, R., Gibelli, M. C., \& Rigamonti, P. I costi collettivi della città dispersa, Alinea, Firenze, 2002.

[38] Latour, B. Politiques de la nature. La Decouverte, Paris, 1999.

[39] Keil, R., \& Desfor, G. Nature and the city: Making environmental policy in Toronto and Los Angeles, University of Arizona Press, Tucson, AZ, 2004.

[40] Urban sprawl in Europe: The ignored challenge, EEA Report no. 10/2006. Land Accounts for Europe 1990-2000: Towards Integrated Land and Ecosystem Accounting, EEA Report no. $11 / 2006$.

[41] Christiaanse, K., Zhou, Y. Van Lilong tot Billabong. De meeslepende transformative van Shanghai's stadsbuurten: de Franse Concessie, AM Magazine, 2013, pp. 28-43. See also Chen, T. Enclaves in Transition. Sustainable Living Urban Model Magazine, n.7, 2012, pp. 22-23.

[42] Secchi, B. La città dei ricchi e la città dei poveri. Laterza, Roma-Bari, 2013.

[43] Kantor, P. Varieties of city regionalism and the quest for political cooperation: A comparative perspective. Urban Research and Practice, Vol.1, n.2, 2008, pp. 111-129.

[44] Walk-Space AWARD 2013. Gute Lösungen für das Zufußgehen in Städten und Gemeinden Österreichs. Avalaible at http://www.walk-space.at/index.php/projekte/ walk-space-award/award-2013. Last accessed 17 September 2013.

[45] Manifetso 2020. Avalaible at http://www.manifetso2020.com. Last accessed 30 September 2013.

[46] Spazi Indecisi. Available at http://www.spaziindecisi.it. Last accessed 17 September 2013.

[47] Architecture of Totalitarian Regimes in Urban Managements (ATRIUM). The Architecture of Totalitarian Regimes in Urban Managements is an ambitious project which aims to put into greater focus a key element of 20th century European history, heritage and memory. Available at http://www.atrium-see.eu/. Last accessed 17 September 2013.

[48] Cassatella C., Dall'Ara E., and Storti, M. (eds.) L'opportunità dell'innovazione. Firenze University Press, Firenze, 2007.
[49] L'Agence des espaces verts acquiert, aménage et protège forêts, sites d'intérêt écologique et terres agricoles périurbaines: Une structure régionale sans équivalent sur le territoire français. Available at http://www.iledefrance.fr/ organismes-associes/agence-espaces-verts-ile-france-0. Last accessed 17 September 2013.

[50] Clementi, A., and Perego, F. La metropoli 'spontanea': Il caso di Roma. Di Donato, Bari, 1983.

[51] Scoppetta, C. Territori della frammentazione: Appunti per un progetto possibile. Edizioni Nuova Cultura, Rome, 2009. This study, coordinated by Professor Vieri Quilici, was carried out at the Department of Urban Studies (DipSU) of Roma Tre University and involved researchers from there and the universities of La Sapienza and Tor Vergata in Rome.

[52] Moaavenzadeh, F.; Hanaki, K.; Baccini, P. Future cities: Dynamics and sustainability. Kluwe Academic Publishers, Dordrecht (The Netherlands), 2002.

[53] Magnaghi, A. The urban village: A charter for democracy and sustainable development in the city. Zed Books, London-New York, 2005.

[54] Parco Nord Milano. Available at http://www.parconord.mila no.it. Last accessed 16 September 2013.

[55] Campbell C. Community-led regeneration: A review of literature. Scottish Government Publications, 2011. Available at http://www.scotland.gov.uk/Publications/2011/0 9/08114042/0. Last accessed 14 September 2013.

[56] Pellegrino, M., Maahsen-Milan, A., and Magnaghi, A. Innovation in urban and architectural composition practices: The re-qualification/regeneration project of Ile de Nantes as an example of how uncertainty can be managed in a positive way. In COST Action TU0701, Improving the quality of suburban building stock, Procedia Vol. 2, Final MC meeting, 20th-21st of April 2012. Unife Press, Ferrara (Italy), 2012, pp. $467-472$.

[57] Pellegrino, M. Les dynamiques des possibles. Incertezza e sostenibilità, nelle pratiche di trasformazione urbana, $\mathrm{PhD}$ dissertation, Storia e valorizzazione del patrimonio architettonico, urbanistico e ambientale, Politecnico di Torino (Italy). Milieux cultures, Societé du passé et du present, Université de Paris Ouest Nanterre La Defense, Tutors: S. Gron, A.Magnaghi, C. Vallat, 2010.

[58] Open planning with a focus on resident involvement: München "Theresienhöhe" (Bavaria). Available at http://www.werkstatt-stadt.de/en/projects/111/. Last accessed 17 September 2013.

[59] JSWD Architekten, Chaix \& Morel et Associés, ThyssenKrupp Hauptquartier, Berlin, JOVIS Verlag, 2010.

[60] Gemeinsam mit Michael Hecker: Zwischen Baukunst und Massenproduktion. Denkmalschutz für die Architektur der 1960er und 1970er Jahre? In: Rheinische Heimatpflege n.48, 2011, pp. 103-108. See also Burnham, S. New needs need new techniques: Urban intervention, design and play. In Pollak, S. (ed.), Superstadt! Zur Zukunft der Stadt zwischen Linz. London und Ramallah, Sonderzahl, Wien, 2012 